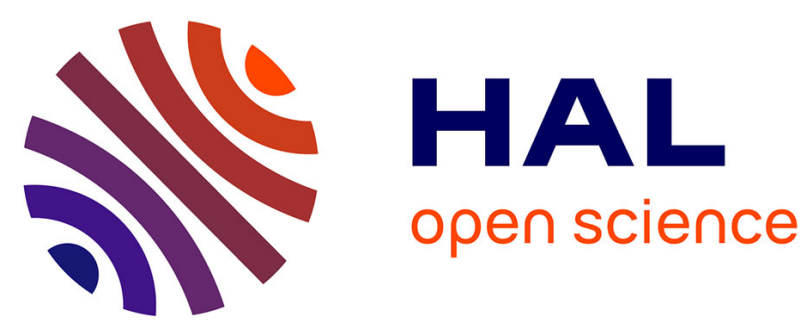

\title{
Cellular energy allocation in the Arctic sea ice amphipod exposed to Water Soluble Fraction of oil
}

Gro Harlaug Olsen, Jolynn Carroll, Eirin Sva, Lionel Camus

\section{To cite this version:}

Gro Harlaug Olsen, Jolynn Carroll, Eirin Sva, Lionel Camus. Cellular energy allocation in the Arctic sea ice amphipod exposed to Water Soluble Fraction of oil. Marine Environmental Research, 2008, 66 (1), pp.213. 10.1016/j.marenvres.2008.02.063 . hal-00563024

\section{HAL Id: hal-00563024 https://hal.science/hal-00563024}

Submitted on 4 Feb 2011

HAL is a multi-disciplinary open access archive for the deposit and dissemination of scientific research documents, whether they are published or not. The documents may come from teaching and research institutions in France or abroad, or from public or private research centers.
L'archive ouverte pluridisciplinaire HAL, est destinée au dépôt et à la diffusion de documents scientifiques de niveau recherche, publiés ou non, émanant des établissements d'enseignement et de recherche français ou étrangers, des laboratoires publics ou privés. 


\section{Accepted Manuscript}

Cellular energy allocation in the Arctic sea ice amphipod Gammarus wilkitzkii exposed to Water Soluble Fraction of oil

Gro Harlaug Olsen, JoLynn Carroll, Eirin Sva, Lionel Camus

PII:

S0141-1136(08)00091-3

DOI:

10.1016/j.marenvres.2008.02.063

Reference:

MERE 3237

To appear in:

Marine Environmental Research

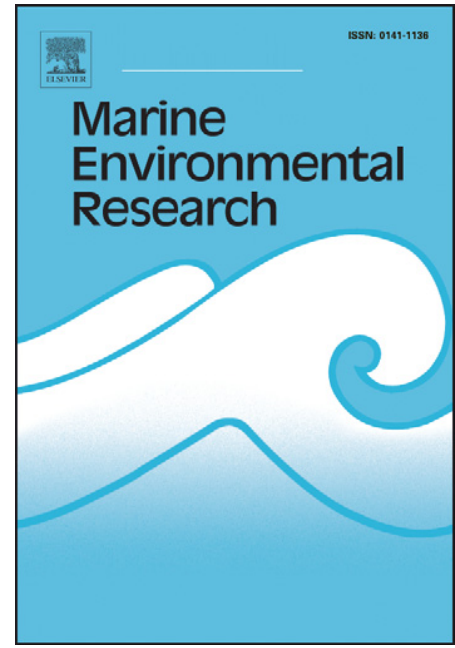

Please cite this article as: Olsen, G.H., Carroll, J., Sva, E., Camus, L., Cellular energy allocation in the Arctic sea ice amphipod Gammarus wilkitzkii exposed to Water Soluble Fraction of oil, Marine Environmental Research (2008), doi: 10.1016/j.marenvres.2008.02.063

This is a PDF file of an unedited manuscript that has been accepted for publication. As a service to our customers we are providing this early version of the manuscript. The manuscript will undergo copyediting, typesetting, and review of the resulting proof before it is published in its final form. Please note that during the production process errors may be discovered which could affect the content, and all legal disclaimers that apply to the journal pertain. 


\title{
Cellular energy allocation in the Arctic sea ice amphipod
}

\section{Gammarus wilkitzkii exposed to Water Soluble Fraction of oil}

\author{
Gro Harlaug Olsen ${ }^{\text {a,b }}$, JoLynn Carroll a , Eirin Sva a , Lionel Camus a,* \\ ${ }^{a}$ Akvaplan-niva, Polar Environmental Center, N-9296 Troms $\phi$, Norway \\ ${ }^{b}$ Norwegian College of Fishery Science, University of Troms $\phi, N-9037$ Troms $\phi$, Norway
}

\begin{abstract}
Increasing offshore oil and gas activities in the European Arctic has raised concerns of the potential anthropogenic impact of oil-related compounds on the polar marine ecosystem. We measured cellular energy allocation (CEA) in the sea ice amphipod Gammarus wilkitzkii after exposure for one month to the water soluble fraction (WSF) of oil. The CEA biomarker measures the energy budget of organisms by biochemically assessing changes in carbohydrates, protein and lipid content as well as the electron transport system activity. A significantly higher protein content was observed in the medium dose compared to controls, while the total energy budget was not affected in G. wilkitzkii. This indicates that parts of the energy budget of G. wilkitzkii, which is a key species in the Arctic ecosystem, is affected by a WSF of oil.
\end{abstract}

Keywords: Arctic; Amphipods; Oil; Cellular energy allocation; Gammarus wilkitzkii 
*Corresponding Author: Tel: +47 777503 13; fax: +47 77750301

E-mail address: lionel@akvaplan.niva.no (L. Camus)

Oil and gas activity in the Barents Sea is increasing as is the risk of accidental discharges, which underscores the need for more information on the effects of oil on Arctic organisms. PAHs have been shown to be some of the most toxic components of crude oil, bioaccumulating in organisms and disrupt cell and tissue function (French-McCay, 2004). To our knowledge no studies have focused on effects of oil-related compounds on sea ice species. In sea ice, amphipods are the dominant organisms and they represent a direct link between lower and higher trophic levels (Lønne and Gulliksen, 1991).

Exposure to pollutants may increase the energy requirement of animals and hence result in reduced energy available for growth and reproduction (Calow and Sibly, 1990). The cellular energy allocation methodology measures energy available (Ea) (protein, lipid and carbohydrate content) and energy consumed (Ec) (electron transport system activity, ETS). Ea and Ec can be combined into a value expressing the net energy budget (De Coen and Janssen, 1997).

In this study, we exposed ovigerous females of the sea ice amphipod G. wilkitzkii to the water soluble fraction of crude oil to investigate whether the energy budget of G. wilkitzkii was altered by sub-lethal concentration of oil. This study is the first application of CEA technique on an Arctic sea ice species.

Ovigerous female specimens of G. wilkitzkii were sampled in August 2006 in the Arctic Ocean (ca. N81 ${ }^{\circ} 43^{\prime}$ E15 $46^{\prime}$ '). To simulate oil spill conditions, an exposure system was set-up according to Carls et al. (1999). After one month exposure Ea, Ec and Cea analyses and 


\section{ACCEPTED MANUSCRIPT}

calculations were performed on each individual (De Coen, 1997). Dissolved PAH concentrations were determined by the modified standard US Environmental Protection Agency (EPA) procedure $3510 \mathrm{C}$. Total PAH concentrations in the water were as follows at day 0 and day 30: high dose, 55-8 ppm; medium dose, 10-2ppm; and low dose, 5-1ppm. The concentrations of PAHs decreased with time and also the relative PAH composition changed, a higher proportion of soluble compounds were found in the beginning and less soluble compounds in the end of the experiment. Ten females per treatment were used, and no replicates were done owing to a limited number of animals. Embryos developmental stages were different between females.

The protein levels were significantly higher in the medium dose compared to controls (Fisher's LSD: $\mathrm{p}=0.02$ ) (Fig. 1), indicating that WSF altered the energy budget related to protein metabolism in G. wilkitzkii. There were no significant differences in any of the other Ea parameters, Ec and CEA (Fig. 2) among treatments (ANOVA p>0.05), indicating that WSF did not affect the other energy parameters.

The higher protein level observed in organisms from the medium dose demonstrates that the WSF affected parts of the energy budget in G. wilkitzkii. A higher protein value can reflect sub lethal stress that induced compensatory changes in the organisms' energy metabolism. This is in accordance with a study from Verslycke et al. (2004) showing protein induction in Neomysis integer from a polluted area. Increased protein level could be caused by an increased lysosomal activity as lysosomes have shown to be a target of toxic stress induced by PAHs and PCBs (Gagnaire et al., 2006). Lysosomal enzymes are considered to play an important role in invertebrate defense reaction systems. Exposure to WSF may therefore have triggered increased production of lysosomal activities, explaining higher protein level in exposed group compared to controls. 


\section{ACCEPTED MANUSCRIPT}

Higher protein levels were observed in the medium dose only. Explanations for this may be that high levels of PAHs may have reduced the physiological response systems (gene and protein expression) in the amphipods receiving high dose.

Negative CEA values were observed in all treatments, including the controls. This indicates that animals used more energy than they were able to allocate to their reserves. It is likely that a reduced food uptake and stress caused these negative values. In all cases, a higher Ec value compared to Ea were measured. This can be explained by the fact that it is assumed that ETS activity is an overestimation of the actual respiration (Båmstedt, 1980).

In the Arctic Ocean, the sea ice amphipod G. wilkitzkii is a key species and provide a link between primary production, detritus and higher trophic levels. Our results show that parts of the energy metabolism of the ice-amphipod were affected by WSF of oil. More time points are needed to definitively link the responses of energy budget parameters to petroleum hydrocarbons, but the results show evidence for disturbed protein metabolisms in G. wilkitzkii exposed to WSF of oil.

\section{Acknowledgements}

This study is financed by the Norwegian Research Council under the program PROOF $\mathrm{N}^{\mathrm{o}} 164407, \mathrm{~N}^{\mathrm{o}} 159016 / \mathrm{S} 40$ and Statoil 'Ice Edge Project'.

\section{References}

Båmstedt, U. (1980). Journal of Experimental Marine Biology and Ecology, 42, 267-283.

Calow, P., and Sibly, R. (1990). Functional Ecology, 4, 283-288.

Carls, M.G., Rice, S.D., and Hose J.E. (1999). Environmental Toxicology and Chemistry 18, 481-493. 
De Coen, W.M., and Janssen, C.R. (1997). Journal of Aquatic Ecosystystem Stress and

Recovery, 6, 43-55.

French-McCay, D.P. (2004) Oil spill impact modeling: development and validation. Environmental Toxicology and Chemistry, 23, 2441-2456.

Gagnaire, B., Thomas-Guyon, H., Burgeot, Th., and Renault, T. (2006). Cell Biology and Toxicology, 22, 1-14.

Lønne, O.J., and Gulliksen, B. (1991). Polar research 10, 289-294.

Verslycke, T., Ghekiere, An., and Janssen, C.R. (2004). Journal of Experimental Biology and Ecology, 306, 245-267. 


\section{Figure caption}

Fig.1. Protein content (mg/g wwt) in Gammarus wilkitzkii in control (C), low dose (LD), medium dose (MD) and high dose (HD) following a 30 day exposure to water-soluble fractions of crude oil. Median ( ), 25 and 75 percentiles (lower and upper bar, respectively) are shown.

Fig. 2. Cellular energy allocation (CEA) in Gammarus wilkitzkii in control (C), low dose (LD), medium dose (MD) and high dose (HD) following a 30 day exposure to water-soluble fractions of crude oil. Median ( ), 25 and 75 percentiles (lower and upper bar, respectively) are shown. 


\section{ACCEPTED MANUSCRIPT}

Figure 1

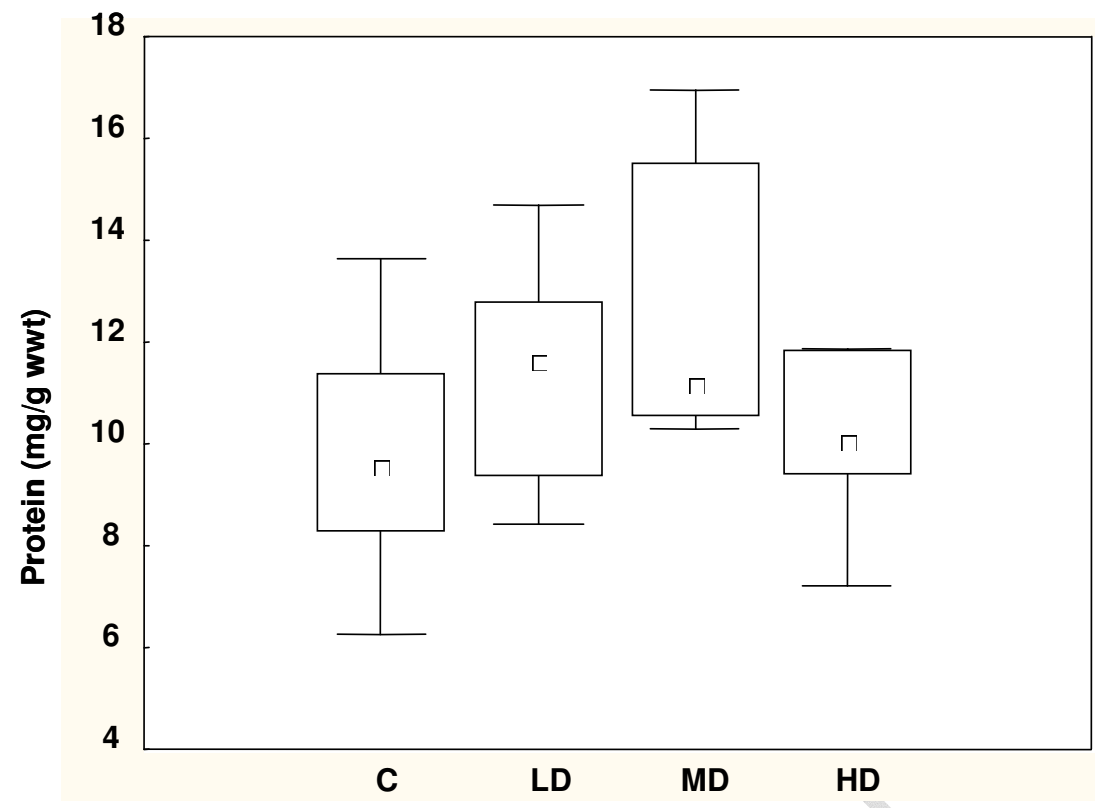




\section{ACCEPTED MANUSCRIPT}

Figure 2

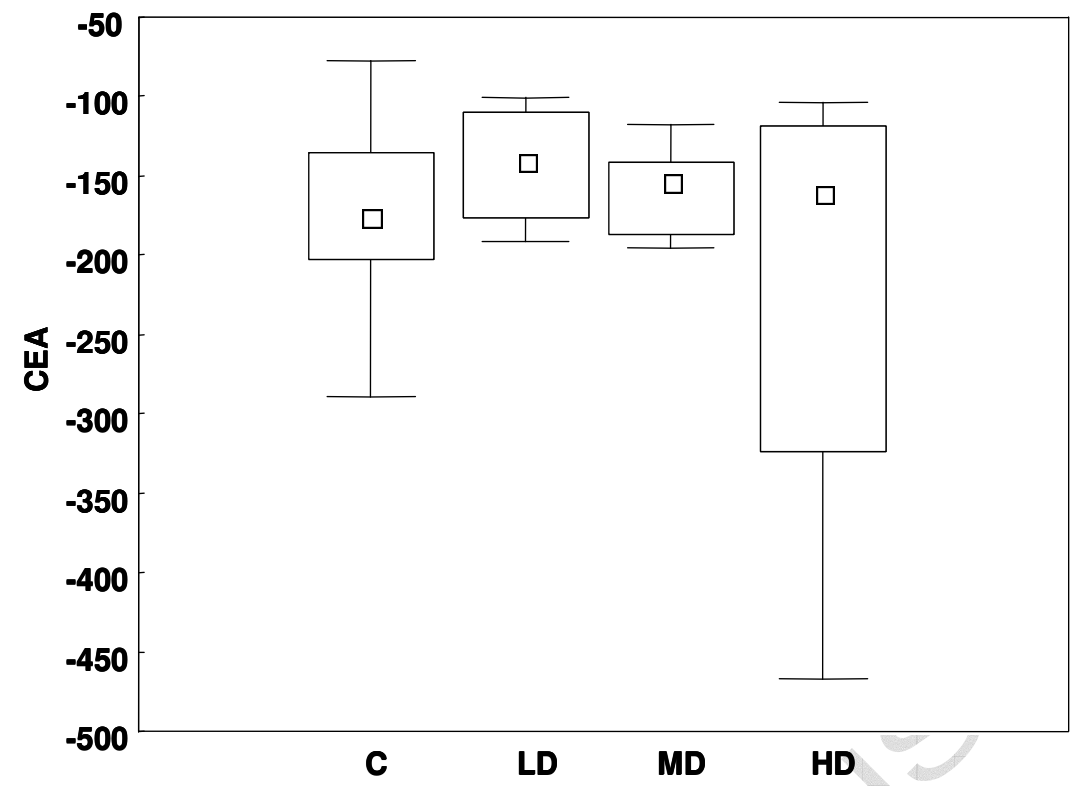

